\title{
Olfactory foraging in Antarctic seabirds: a species-specific attraction to krill odors
}

\author{
Gabrielle Nevitt* \\ Section of Neurobiology, Physiology and Behavior, Division of Biological Sciences, University of California, Davis, \\ California 95616, USA
}

\begin{abstract}
Antarctic procellariiform seabirds are known for their well-developed sense of smell, yet few behavioral experiments have addressed how these birds use olfactory cues to forage at sea. I describe results from controlled, shipboard experiments performed in Antarctic waters near Elephant Island. Birds were presented with plain or krill-scented (Euphausia superba) vegetable oil slicks, and their behavioral responses were compared. Krill-scented vegetable oil slicks were highly attractive to some but not all procellariiform species foraging in this area $(\mathrm{p}<0.001, G$-test). Cape petrels Daption capense and southern giant petrels Macronectes giganteus appeared at krill-scented slicks within $1 \mathrm{~min}$, whereas black-browed albatrosses Diomedea melanophris appeared within 3 min. Cape petrels $D$. capense showed the strongest attraction: these birds were observed as much as 5 times as frequently at krill-scented slicks as compared to unscented control slicks ( $p<0.001, G$-test), while storm-petrels (Oceanites oceanicus and Fregetta tropica) and Antarctic Fulmars Fulmarus glacialoides responded in equal numbers to krill-scented and unscented slicks. When considered with respect to previously published findings, these results suggest a greater complexity in the significance of odors to the foraging ecology of different tube-nosed species than has commonly been assumed.
\end{abstract}

KEY WORDS: Procellariiform · Olfaction · Antarctica $\cdot$ Petrels $\cdot$ Seabirds $\cdot$ Foraging $\cdot$ Krill

\section{INTRODUCTION}

Procellariiform or 'tube-nosed' seabirds (i.e. the petrels, the albatrosses and the shearwaters) have a remarkably developed olfactory neuro-anatomy compared to many other birds (Bang 1965, 1966, Wenzel 1987, Wenzel \& Meisami 1990). Tube-nosed seabirds are also readily attracted to fishy-smelling compounds deployed at sea (e.g. cod liver or tuna oil, fish homogenates, etc $i$ Grubb 1972, Hutchison \& Wenzel 1980, Hutchison et al. 1984, LeQuette et al. 1989, Verheyden \& Jouventin 1994, Nevitt et al. 1995). These observations suggest that a keen sense of smell may play an important role in locating patchily distributed food resources in the ocean.

Antarctic krill Euphausia superba is a preferred prey of many petrel species (Croxall \& Prince 1980, Prince \& Morgan 1987) and it is intriguing to speculate that pro-

•E-mail: ganevitt@ucdavis.edu cellariiforms may be able to hunt krill swarms using a foraging strategy based in part on smell. Both whole krill homogenates ( $E$. superba) and component odors derived from krill have recently been shown to attract at least 2 species of petrels in the Northern Hemisphere (sooty shearwaters Puffinus griseus: Hutchison et al. 1984; Leach's storm-petrels Oceanodroma leucorhoa: Clark \& Shah 1992). Although their behavioral experiments were performed ashore near breeding colonies, Clark \& Shah (1992) provide quantitative support that krill-derived odors might serve as attractants to petrels foraging at sea. Through simulation studies of dispersion profiles of volatiles (e.g. pyrazine) released by macerating krill, they speculate that a relatively small $\left(0.5 \mathrm{~m}^{2}\right)$ patch of krill may be detectable to foraging petrels from distances on the order of kilometers. This is a provocative idea since many tubenosed species live highly pelagic lifestyles, often foraging in dim light over large stretches of open ocean where krill swarms can be small and highly patchily distributed (Croxall \& Prince 1987). 
This initial study tests the hypothesis that Antarctic tube-nosed seabirds use odor cues to locate krill patches at sea. Working in the waters off Elephant Island near the Antarctic Peninsula, I found that krillscented vegetable oil slicks were highly attractive to some but not all procellariiform species foraging in this area. These findings add to previously published studies investigating olfactory responses of Antarctic procellariiform seabirds to other odors associated with krill (Nevitt et al. 1995). They also suggest a greater complexity in the significance of odors to the foraging ecology of different tube-nosed species.

\section{METHODS}

Observations were made aboard the NOAA Research Vessel 'Surveyor' during February and March 1993 at the northwest tip of the Antarctic Peninsula near Elephant and Seal Islands (Fig. 1A,B). The study was carried out as part of the National Oceanic and Atmospheric Administration's (NOAA) Antarctic Marine Living Resources (AMLR) program. A description of cruise activities is given elsewhere (Rosenberg 1993).

Odor experiments. To test the responsiveness of procellariiform seabirds to krill odors, I presented odors as scented vegetable oil slicks deployed on the surface of the water (see Nevitt et al. 1995). Slicks were tested at 4 stations along the AMLR transect grid ( Fig. 1B). While the ship was positioned into the wind, either an unscented or a krill-scented vegetable oil slick was deployed from the stern such that the slick drifted well away $(100 \mathrm{~m})$ from the ship. Unscented slicks were tested to control for any visual attraction that the oil slick might present to foraging seabirds. From 1 min prior to slick deployment (time zero), a team of 2 observers recorded numbers and species of new arrivals using handheld computers or dictaphones. At the start of an experimental trial, an initial or 'pre' count was made in a $300 \mathrm{~m}$ arc around the stern of the ship to estimate numbers and species of birds nearby before the experiment was begun (gray bars, in Figs. $2 \& 3$ ). Once the slick was deployed, a bird was counted as showing interest if it (1) flew upwind within 1. $m$ of the surface of the slick, (2) alighted on the slick or (3) pattered on the slick. Data were sampled continuously in 1 min intervals over 6 min (Martin \& Bateson 1993). Trials were limited to 6 min to reduce the potentially confounding effects of visual cueing by birds landing on the slick. Each bird was counted only once. Observers were blind to the treatments being tested. and the experimental and control trials were presented in random order at each location. All experiments were conducted during daylight hours when weather conditions were relatively calm (Table 1).
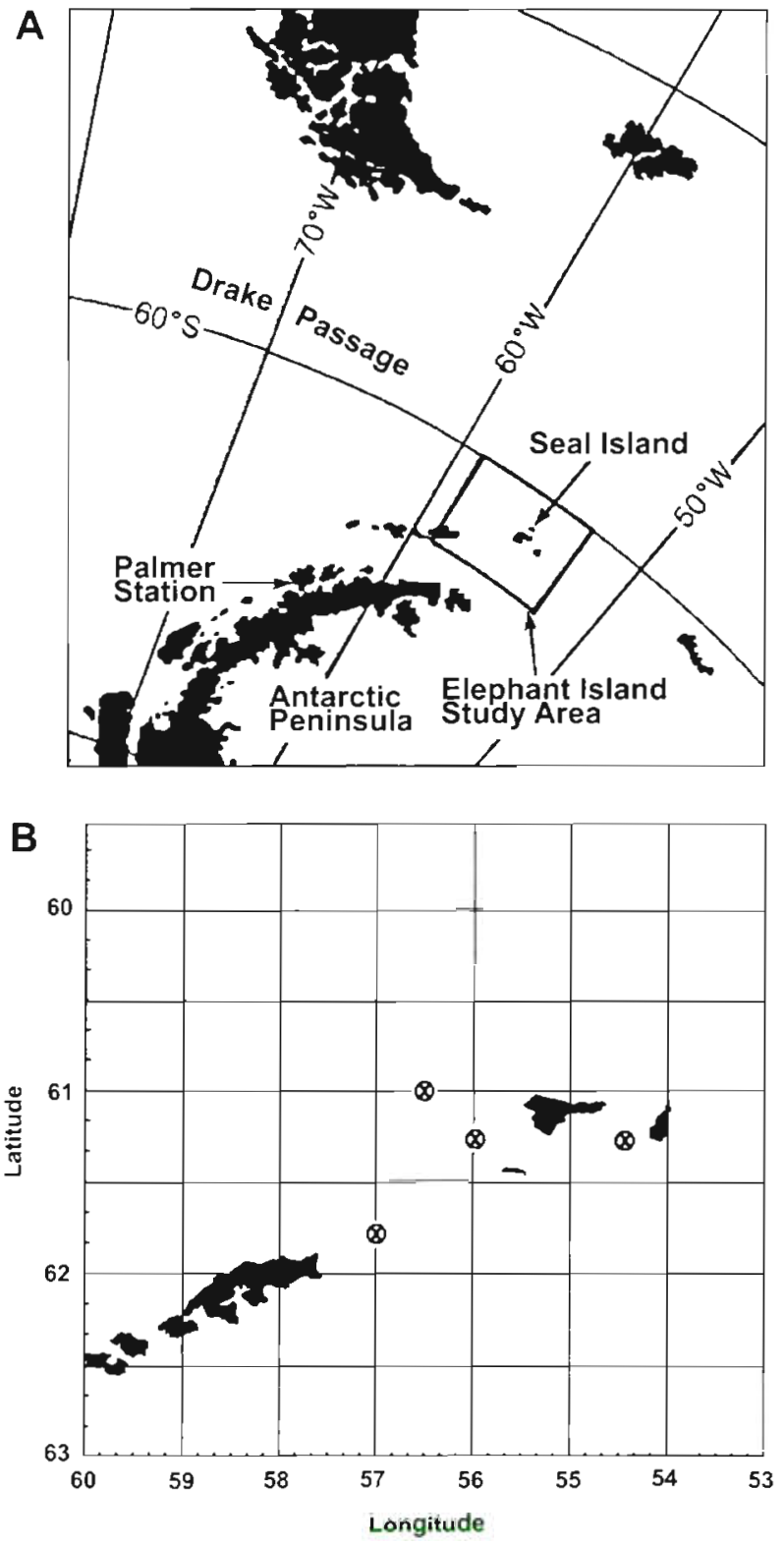

Fig. 1. (A) Elephant Island AMLR study area and Seal Island (arrows). (B) Detail of the AMLR study area. $(\otimes)$ Locations where olfactory studies were performed

Krill-scented oil was prepared by macerating 2.51 of fresh whole Antarctic krill Euphausia superba. The homogenate was then strained through a fine wire mesh to remove solids. The remaining liquid fraction was filtered and diluted to $2.5 \mathrm{I}$ with vegetable oil. This process was always performed 1 h before the experiment was to begin. Once deployed, slicks spread to as much as $20 \mathrm{~m}$ in diameter.

Underway observations. To determine 'background' species compositions (see Fig. 4), all birds within a $100 \mathrm{~m}$ wide 'box' $50 \mathrm{~m}$ off the bow of the ship were counted using standard strip transect methodology 
Table 1. Summary of environmental conditions during experimental trials. Data were recorded by standard shipboard instrumentation (Rosenberg 1993)

\begin{tabular}{|lc|}
\hline Environmental parameter & Range \\
\hline Air temperature $\left({ }^{\circ} \mathrm{C}\right)$ & $1.6-2.5$ \\
Surface sea temperature $\left({ }^{\circ} \mathrm{C}\right)$ & $-1.0-1.1$ \\
Barometric pressure $(\mathrm{mb})$ & $1002.4-1013.0$ \\
Relative humidity $(\%)$ & $96.6-96.7$ \\
True wind speed $(\mathrm{knots})$ & $3.6-12.5$ \\
Solar radiation, PAR (quanta $\left.\mathrm{cm}^{-2} \mathrm{~s}^{-1}\right)$ & $1.53-3.47$ \\
\hline
\end{tabular}

(Tasker et al. 1984) for a $5 \mathrm{n}$ mile transect leading up to the station. Observers worked in pairs, with 1 person watching through binoculars while the other entered these observations into a portable computer. The time of observation, behavior, and instantaneous flight direction were also recorded.

Other shipboard observations. During transect observations, the ship surveyed local krill abundance using 120 and $200 \mathrm{kHz}$ acoustic transducers mounted on a weighted towed body. Olfactory experiments were conducted in areas where krill was not detected ( $<1 \mathrm{~m}^{-2}$; Rosenberg 1993, R. Hewitt pers. comm.). Environmental parameters were recorded by shipboard instrumentation. Ranges recorded during experimental trials are given in Table 1.

\section{RESULTS}

Within 1 min, cape petrels Daption capense and Southern Giant Petrels Macronectes giganteus appeared at krill-scented slicks (Figs. 2 \& 3A,B). By 6 min, procellariiform species were sighted as much as 5 times as frequently at slicks scented with crude krill extract than at unscented control slicks (Fig. 2; p < 0.001, G-test for pooled data, df $=1$; Zar 1996), but the relative attractiveness of this odor differed markedly among species. Cape petrels $D$. capense were by far the strongest responders, flying into krill-scented slicks as much as 5 times as frequently as into unscented vegetable oil slicks (Fig. 3A; p $<0.001$, G-test for pooled data, $d f=1$ ). Southern giant petrels (Fig. 3B; M. giganteus), and black-browed albatrosses (Fig. 3Ci Diomedea melanophris) were sighted only at krillscented slicks and never at unscented vegetable oil slicks, but numbers were too low to allow for a statistical analysis.

Behaviors were also markedly different at krillscented and unscented slicks. Cape petrels Daption capense and southern giant petrels Macronectes giganteus typically flew upwind into krill-scented slicks where they alighted and were frequently observed to

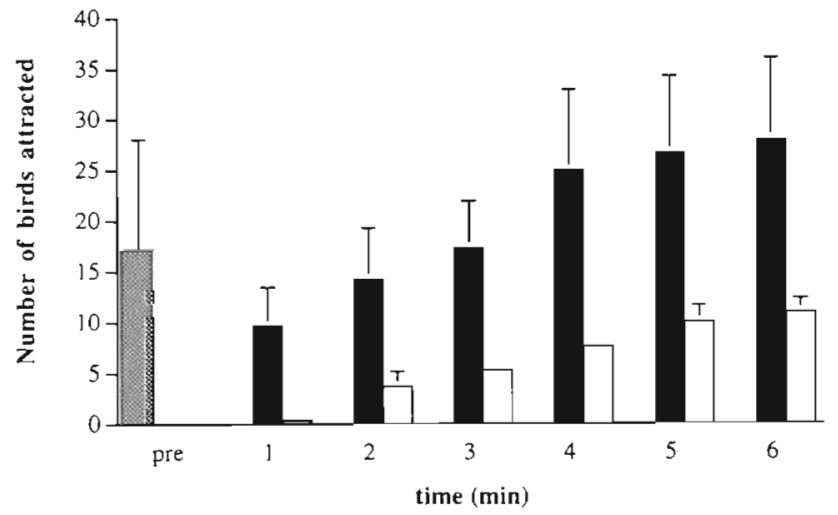

Fig. 2. Total birds attracted to krill-scented (black bars) and control slicks (white bars) presented at the 4 locations indicated in Fig. 1. At the start of an experimental trial, an initial or 'pre' (gray bar) count was made in a $300 \mathrm{~m}$ arc around the stern of the ship to estimate numbers and species of birds nearby before the experiment was begun, and shows the total number of birds around the ship before slicks were deployed (see 'Methods')

dip their bills into the water. Cape petrels $D$. capense rarely (1 observation) alighted on unscented control slicks. Birds that were attracted to these slicks did not approach them from any particular direction. These few individuals typically circled the general area approximately $1 \mathrm{~m}$ above the water and then left.

Other procellariiform species showed no difference in their responses to krill-scented and unscented slicks. Storm-petrels (Fig. 3D; Oceanites oceanicus and Fregetta tropica) and Antarctic fulmars (Fig. 3E; Fulmarus glacialoides) were sighted in nearly equal numbers under either condition. We frequently observed storm-petrels pattering on the surface of both krillscented and unscented slicks. Zigzag flying, indicative of an olfactory search behavior (Hutchison \& Wenzel 1980), was noted when birds approached krill-scented slicks. Storm-petrels tended to arrive at slicks 1 or 2 at a time and patter in small groups near the upwind edges of the slicks, typically several meters from other birds.

The observed frequencies of species at slicks did not reflect the relative abundances of these species in the area (Fig. 4). Cape petrels Daption capense, for example, accounted for only $12 \%$ of the background species composition but made up $58 \%$ of those birds present at slicks scented with krill (Fig. 4A). In contrast, Antarctic fulmars Fulmarus glacialoides were by far the most abundant procellariiform seabird in the immediate vicinity (Fig. 4A,B, 78\%), but were only rarely observed at either krill-scented or unscented slicks (i.e. contrast Fig. 4A and Fig. 3E). The relative proportion of storm-petrels was on the order of 5 to 13 times higher at krill-scented and unscented slicks respectively than would be expected from relative abundances of these 

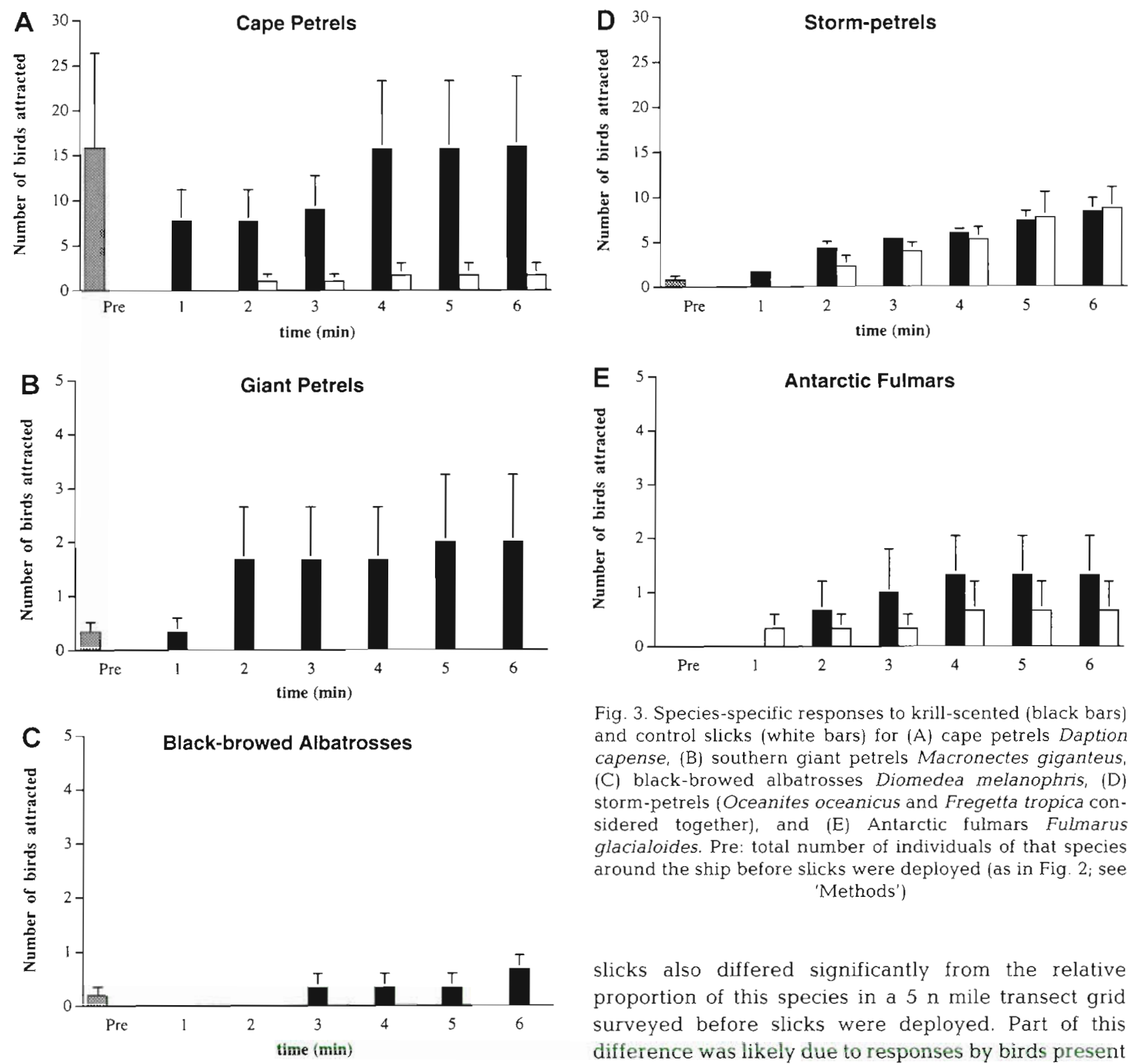

Fig. 3. Species-specific responses to krill-scented (black bars) and control slicks (white bars) for (A) cape petrels Daption capense, (B) southern giant petrels Macronectes giganteus, (C) black-browed albatrosses Diomedea melanophris, (D) storm-petrels (Oceanites oceanicus and Fregetta tropica considered together), and (E) Antarctic fulmars Fulmarus glacialoides. Pre: total number of individuals of that species around the ship before slicks were deployed (as in Fig. 2; see 'Methods')

birds in the area based on surveys during transects (Fig. 4A,B). Together these results suggest that stormpetrels actively recruited to slicks, but that this behavior was not related to the particular scent of the slicks.

\section{DISCUSSION}

These results support the hypothesis that odors from macerated krill serve as foraging cues for certain procellariiform seabirds. Cape petrels Daption capense in particular approached krill-scented slicks in dramatically higher numbers than control slicks. The relative proportion of cape petrels $D$. capense at krill-scented

slicks also differed significantly from the relative proportion of this species in a $5 \mathrm{n}$ mile transect grid surveyed before slicks were deployed. Part of this difference was likely due to responses by birds present immediately around the ship before experiments began (see Fig. 3A, 'pre' bar). However, while these individuals rapidly accumulated at krill-scented slicks, they showed little interest in unscented control slicks, suggesting that krill odor was the key stimulus evoking the attraction. In support of this idea, Antarctic krill Euphausia superba is known to be a primary component of the diet of many cape petrel populations studied during the breeding season, which coincides with the time of year when the present studies were carried out (Croxall \& Prince 1980, 1987, Ainley et al. 1984, Croxall et al. 1984). Reports from AMLR-related bird research carried out on Seal Island also indicate that cape petrels $D$. capense in the area were provisioning chicks with krill while olfactory studies were being conducted (Jansen et al. 1993). This information pro- 
vides compelling evidence that at least some of the local cape petrels $D$. capense were actively hunting krill during this general time.

Despite the strong attraction of cape petrels Daption capense to krill-scented slicks, storm-petrels responded to krill-scented and unscented slicks almost identically. Still, the relative proportion of storm-petrels was higher at both experimental and control slicks than would be expected from our estimates of the relative background species composition (Fig. 4A,B). Storm-petrels were clearly recruited from some distance to the slicks, since the numbers of recruits exceeded initial numbers of birds observed around the ship before slicks were deployed (Fig. 3D). These observations may also indicate that storm-petrels were attracted to visual stimuli such as the sheen of the slicks on the surface of the water, to social cueing by conspecifics and other birds, or to the scent of the vegetable oil itself.

While it is possible that these highly olfactory birds were lured to the scent of the organic compounds in vegetable oil, lacing slicks with natural odors has been shown to significantly enhance recruitment by stormpetrels in other studies. For example, both Wilson's and black-bellied storm-petrels (Oceanites oceanicus and Fregetta tropica) were attracted more quickly and in higher numbers to fishy odors and other scented compounds associated with Antarctic krill Euphausia superba than to vegetable oil (Nevitt et al. 1995). In the present study, storm-petrels tended to arrive within 1 min following the deployment of krill-scented slicks, as compared to a 2 min latency in arrival at control slicks. But if this decrease in response time was mediated by an olfactory attraction, then it was a relatively weak attraction compared to olfactory behaviors observed in other procellariiforms in response to other food-related odors (e.g. cod liver or tuna oil, fish homogenates; Grubb 1972, Hutchison \& Wenzel 1980, Hutchison et al. 1984, LeQuette et al. 1989, Verheyden \& Jouventin 1994, Nevitt et al. 1995). Moreover, the lack of significant recruitment to krill-scented slicks does not reflect a lack of krill in storm-petrel diets since several reports indicate that Antarctic krill E. superba is one of their most important foods (e.g. $93 \%$ of prey items, Ainley et al. 1984; $85 \%$ prey mass, Obst 1985).

Antarctic fulmars Fulmarus glacialoides were the most numerous of all birds along the $5 \mathrm{n}$ mile transect grids surveyed, but were rarely seen at either experimental or control slicks ( $76 \%$ of background composition vs $5 \%$ of birds at krill-scented slicks). Little data is available about the diets of Antarctic fulmars $F$. glacialoides, though one study suggests that krill makes up as much as $52 \%$ by mass of their diet during the breeding season in other parts of the Antarctic (Hodum 1999). Other data collected in October from oceanic habitat north of the Ross sea and in the Scotia-
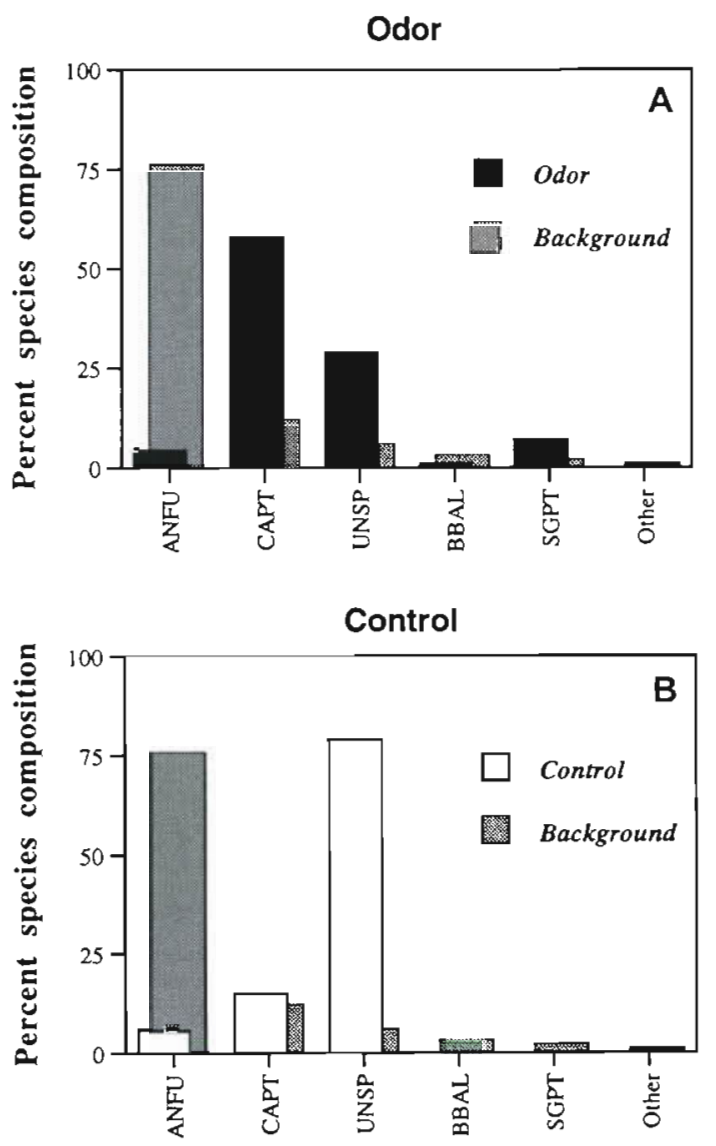

Fig. 4. Species composition of birds at slicks as compared to species composition of birds observed during transect surveys. (A) Observed frequencies of species at krill-scented slicks (black bars) with respect to background frequencies (gray bars) as determined by survey counts (see 'Methods'). Observed frequencies at scented slicks are significantly different from background frequencies ( $\mathrm{p}<0.001 ; \chi^{2}$ test for goodness-of-fit; $d f=5$ ). (B) Observed frequencies of species at unscented control slicks (white bars) with respect to background frequencies (gray bars) as determined by survey counts during transects. Observed frequencies at control slicks are significantly different from background frequencies $\left(\mathrm{p}<0.001 ; \chi^{2}\right.$ test for goodness-of-fit; df $=5$ ). Species codes are ANFU (Antarctic fulmar), CAPT (cape petrel Daption capense), UNSP (unidentified storm-petrel; Oceanites oceanicus and Fregetta tropica considered together), BBAL (blackbrowed albatross Diomedea melanophris, and SGPT (southern giant petrel Macronectes giganteus]

Weddell confluence suggest that these birds are primarily nocturnal foragers and that krill $E$. superba is not a primary target (Ainley et al. 1984). Krill ( $E$. superbal and other crustacea constituted less than $10 \%$ composition by weight whereas cephalopods (most notably Gonatus antarcticus, Psychronteuthis glacialis and Galituethis glacialis) and lantern fish Electrona antarctica made up the bulk of diets sampled. Thus, in my study it is possible that Antarctic fulmars $F$. glacialoides did not respond to krill scent 
simply because they were hunting other prey, or foraging at night.

\section{Different foraging strategies?}

The differences in the attraction of different procellariiform species to krill-scented slicks may reflect not only discrepancies in diet, but also a species-specific divergence in foraging strategies. Wilson's stormpetrels Oceanites oceanicus are known to feed on Antarctic krill Euphausia superba and other crustacea (Obst 1985, Croxall et al. 1988), yet these birds are not preferentially attracted to odors derived from crushed krill any more than to plain vegetable oil. It has been shown, however, that both Wilson's and black-bellied storm-petrels (O. oceanicus and Fregetta tropica) are highly attracted to a different odor associated with krill swarms, dimethyl sulfide (DMS; Nevitt, et al 1995). This odor is not released by krill, but by phytoplankton (most notably, Phaeocystis sp.) in response to grazing by E. superba and other zooplankton (Dacey \& Wakeham 1986, Daly \& DiTullio 1996). Since DMS levels tend to be high in areas where productivity is also high (McTaggart \& Burton 1992), the ability to detect DMS and use it as a foraging cue could thus be advantageous in locating and exploiting zooplankton-rich foraging areas.

However, both Wilson's and black-bellied stormpetrels $(O$. oceanicus and Fregetta tropica) were highly attracted to DMS in these studies whereas cape petrels Daption capense were not. These birds were just as likely to approach DMS-scented slicks as unscented control slicks. Why might this be? One hypothesis that merits further study is that these distinctive olfactory cues may present conflicting information about foraging opportunities, depending on the species. Just as DMS is released when phytoplankton is grazed by zooplankton, krill extracts are likely to be released when krill is being eaten by larger predators, as during large-scale, multi-species feeding events (Hunt et al. 1988). Since Antarctic krill Euphausia superba is a patchily distributed and often ephemeral food resource in the southern oceans (Hamner et al. 1983), these feeding flocks form when and where large krill swarms become accessible, and may persist for several days (e.g. Harrison et al. 1991). In such situations, aggressive, large procellariiform species can effectively compete with other birds and mammals for krill and other potential prey species that are attracted to krill swarms. It seems logical to predict that such birds might be attracted to scents produced from macerated krill, and that these aromatic signposts serve as indicators that krill is readily accessible to them, possibly beyond the visual range (Clark \& Shah 1992).
Storm-petrels, however, are relatively tiny birds that may just as conveniently serve as prey to larger petrels, particularly southern giant petrels (Macronectes giganteus; Hunter 1983, Nevitt pers. obs.), frequenting these feeding aggregations. Storm-petrels may not be attracted to macerated krill scent simply due to the increased risk of predation that this cue may present to them. Detailed studies of mixed species feeding aggregations near South Georgia support this view in that black-browed albatrosses Diomedea melanophris, southern giant petrels $M$. giganteus and cape petrels Daption capense were observed nearly 20 times as frequently as storm-petrels at such feeding events (2863 vs 150; Harrison et al. 1991). When present, storm-petrels tended to be restricted to the perimeter of flocks. In the present study, storm-petrels only recruited to slicks in large $(>10)$ numbers where cape petrels $D$. capense and giant petrels $M$. giganteus were absent, though all these species were abundant during transect surveys between stations.

\section{Future directions}

One of the challenges facing the study of olfactory behaviors is in determining what odor cues constitute biologically and ecologically relevant signals, in this case for foraging seabirds. The results presented here offer the compelling suggestion that procellariiform seabirds follow fundamentally different olfactory strategies for locating patchily distributed prey at sea, but we are far from understanding the complexities of these behaviors. Based on the data available at this time, I have offered a simple hypothesis for why some species might avoid krill extract, but this theory does not explain the species-specific attraction we have observed to other prey-related odorants (DMS). To date, only 2 published studies on Antarctic procellariiforms have addressed olfaction in the context of foraging at sea (Verheyden \& Jouventin 1994, Nevitt et al. 1995). The study presented here thus also serves to demonstrate a simple experimental approach for investigating such problems from standard research vessels, with a view towards stimulating more research in this area. Current studies are under way to explore these questions in greater detail.

Acknowledgements. Thanks to Beverly Agler, Dr Martha Groom and Dr David Secord for their expert assistance in the field. I am also grateful to Dr Peter Kareiva, Dr Richard Veit, Dr Roger Hewitt and the National Oceanic and Atmospheric Administration (NOAA) for logistical assistance and support of my work, and to the Captain, crew and scientists aboard RV 'Surveyor'. The comments of Lisa Holsinger, Jason Watters, Keith Reid, and 3 anonymous reviewers improved the quality of this manuscript. This work was funded in part by NSF grant OPP \# 9220128 to P. Kareiva, R. Veit, and J. Wingfield and OPP \# 9615061 to G.N. 


\section{LITERATURE CITED}

Ainley DG, O'Connor EF, Boekelheide RJ (1984) The marine ecology of the birds in the Ross Sea, Antarctica. A Ornithol Monogr 32:1-97

Bang BG (1965) Anatomical adaptations for olfaction in the snow petrel. Nature 205:513-515

Bang BG (1966) The olfactory apparatus of tubenosed birds. Acta Anat 65:391-415

Clark L, Shah PS (1992) Information content of odor plumes: what do Leach's storm-petrels know? In: Doty RL, MüllerSchwarze D (eds) Chemical signals in vertebrates VI. Plenum Press, New York, p 421-427

Croxall JP, Prince PA (1980) Food, feeding ecology and ecological segregation of seabirds at South Georgia. Biol J Linn Soc 14:103-131

Croxall JP, Rickets C, Prince. PA (1984) Impact of seabirds on marine sources, especially krill of South Georgia waters. In: Whittow GC, Rahn H (eds) Seabird energetics. Plenum Press, New York, p 285-317

Croxall JP, Hill HJ, Lidstone-Scott $R, O^{\prime}$ Connell MJ, Prince PA (1988) Food and feeding ecology of Wilson's storm-petrel Oceanites oceanicus at South Georgia. J Zool Lond 216: 83-102

Croxall JP, Prince PA (1987) Seabird as predators on marine resources, especially krill, at South Georgia. In: Croxall JP (ed) Seabirds: feeding ecology and role in marine ecosystems. Cambridge University Press, Cambridge, p 345-368

Dacey JWH, Wakeham SG (1986) Oceanic dimethylsulfide: production during zooplankton grazing on phytoplankton. Science 233:1314-1316

Daly KL, DiTullio GR (1996) Particulate dimethylsulfoniopropionate removal and dimethyl sulfide production by zooplankton in the Southern Ocean. In: Kiene RP, Visscher PT, Kellor MD, Kirst GO (eds) Biological and environmental chemistry of DMSP and related sulfonium compounds. Plenum Press, New York, p 223-238

Grubb T (1972) Smelling and foraging in petrels and shearwaters. Nature 237:404-405

Hamner WH, Hamner P, Strand S, Gilmer R (1983) Behavior of Antarctic krill, Euphausia superba: chemoreception, feeding, schooling, and molting. Science 220 : $433-435$

Harrison NM, Whitehouse MJ, Heinemann D, Prince PA, Hunt GL Jr, Veit RR (1991) Observations of multispecies feeding flocks around South Georgia. Auk 108: $801-810$

Hodum PJ (1999) Foraging ecology and reproductive energetics of Antarctic fulmarine petrels. PhD diss, University of California, Davis

Hunt GL Jr, Harrison M, Hamner WM, Obst BS (1988) Observations of a mixed species flock of birds foraging on euphausiids near St. Matthews Island in the Bering Sea Auk 105:345-349

Editorial responsibility: Otto Kinne (Editor),

Oldendorf/Luhe, Germany
Hunter S (1983) The food and feeding ecology of the giant petrels Macronectes halli and M. gigantens at South Georgia. J Zool Lond 200:521-538

Hutchison L, Wenzel BM (1980) Olfactory guidance in foraging by procellariiforms. Condor 82:314-319

Hutchison L, Wenzel BM, Stager KE, Tedford BL (1984) Further evidence for olfactory foraging by sooty shearwaters and northern fulmars. In: Nettleship DN, Sanger GA, Springer PF (eds), Marine birds: their feeding ecology and commercial fisheries relationships. Special Publication Canadian Wildlife Service, Ottawa, p 72-77

Jansen J, Meyer K, Bengston JL, Croll DA (1993) Seabird research at Seal Island, Antarctica during 1992/93. In Rosenberg J (ed) AMLR 1992/93 Field Season Report. Administrative Report \#LJ-93-08, Southwest Fisheries Science Center, p 96-102

LeQuette B, Verheyden C, Jouventin P (1989) Olfaction in subantarctic seabirds: its phylogenetic and ecological significance. Condor 91:732-735

Martin P, Bateson P (1993). Measuring behavior. Cambridge University Press, Cambridge

McTaggart AR, Burton H (1992) Dimethyl sulfide concentrations in the surface waters of the Australasian Antarctic and Subantarctic oceans during an austral summer. J Geophys Res 97 (C9):14407-14412

Nevitt GA, Veit RR, Kareiva P (1995) Dimethyl sulphide as a foraging cue for Antarctic procellarifform seabirds. Nature $376: 680-682$

Obst BS (1985) Densities of Antarctic seabirds at sea and the presence of the krill Euphausia superba. Auk 102:540-549

Prince PA, Morgan RA (1987) Diet and feeding ecology of Procellariiformes. In: Croxall JP (ed) Seabirds: feeding ecology and role in marine ecosystems. Cambridge University Press, Cambridge, p 135-171

Rosenberg J (ed) (1993) United States Antarctic Marine Living Resources (AMLR) 1992/93 Field Season Report, Administrative Report LJ-93-08. Southwest Fisheries Science Center, National Marine Fisheries Service, La Jolla, CA

Tasker ML, Jones PH, Dixon T, Blake BF (1984) Counting seabirds at sea from ships: a review of the methods employed and suggestions for a standardized approach. Auk 10(3):567-577

Verheyden C, Jouventin P (1994) Olfactory behavior of foraging procellariiforms. Auk 111:285-291

Wenzel BM (1987) The olfactory and related systems in birds. In: Demski LS, Schwanzel-Fukuda M (eds) The terminal nerve (nervus terminalis): structure, function and evolution. Annls NY Acad Sci 519:137-149

Wenzel BM, Meisami E (1990) Quantitative characteristics of the olfactory system of the northern fulmar (Fulmarus glacialis): a pattern for sensitive odor detection? In: Doving $\mathrm{KB}$ (ed) 10th International Symposium on Olfaction and Taste. GCS A/S, Oslo, p 379

Zar JH (1996) Biostatistical analysis, 3rd edn Prentice Hall, Upper Saddle River, NJ

Submitted: June 22, 1998; Accepted: October 9, 1998

Proofs received from author(s): February 4, 1999 